\title{
Novel drugs and
}

\section{intervention strategies for the treatment of chronic kidney disease}

\section{Hiddo Jan Lambers Heerspink \& Dick de Zeeuw}

Department of Clinical Pharmacology, University Medical Center Groningen, University of Groningen,

Groningen, the Netherlands

\section{Correspondence}

Dr Hiddo Lambers Heerspink PharmD, Department of Clinical Pharmacology, University Medical Center Groningen, University of Groningen, Ant. Deusinglaan 1,9713 AV Groningen, the Netherlands. Tel.: +31503632810

Fax: +31 503632812

E-mail:h.j.lambers.heerspink@umcg.nl

\section{Keywords}

chronic kidney disease, drugs, nephropathy, personalized medicine, therapy

\section{Received}

19 April 2013

Accepted

20 June 2013

Accepted Article

Published Online

26 June 2013

Chronic kidney disease (CKD) is a worldwide health problem. The disease is most often progressive of nature with a high impact on patients and society. It is increasingly recognized that CKD can be detected in the early stages and should be managed as early as possible. Treatment of the cause, but in particular control of the main risk markers, such as high blood pressure, glucose and albuminuria, has been instrumental in delaying the progression to end-stage renal disease (ESRD). However, despite the state of the art therapy, the absolute risk of renal and cardiovascular morbidity and mortality in CKD patients remains devastatingly high. Novel drugs are therefore highly desirable to halt effectively the progressive renal (and cardiovascular) function loss. Recently, several novel strategies have been tested targeting traditional risk factors such as blood pressure (combination therapy of angiotensin converting enzyme inhibitors (ACEi) and angiotensin receptor blockers (ARB) and novel mineralocorticoid receptor antagonists) as well as dyslipidaemia (statins) with surprising results. In addition, drug targets specifically related to the kidney, such as vitamin D, uric acid, erythropoietin and phosphate, have been the subject of clinical trials, in some instances with unexpected results. Finally, novel targets including endothelin receptors and inflammatory pathways are increasingly explored as potential avenues to improve renal and cardiovascular protection, albeit that the drugs tested have not been unequivocally successful. In this article we review novel drugs or intervention strategies for the management of CKD, we try to provide explanations for the failure of some promising drugs and hypothesize on the potential success of new strategies.

\section{Introduction}

\section{Epidemiology}

People with impaired kidney function face a high risk of progressive renal function loss. This often leads to complete loss of kidney function, so called end-stage renal disease (ESRD) for which people require ongoing dialysis or renal transplantation. In addition to the high incidence of ESRD, there is an even higher risk in these chronic kidney disease (CKD) patients for cardiovascular complications or premature mortality even before they start dialysis. The provision of dialysis places a high burden on individual patients as well as on national health care budgets and society. For example, in Europe, average health care expenditure for a patient with ESRD is around 40.000 euros per year [1].

Many studies over the last decades in various populations have shown that low estimated glomerular filtration rate (eGFR) or proteinuria are associated with renal disease progression. In a recent meta-analysis involving more than 1 million individuals it was shown that the risk gradient for ESRD according to eGFR is flat at eGFR above approximately $70 \mathrm{ml} \mathrm{min}^{-1} 1.73 \mathrm{~m}^{-2}$ and linearly increases below this level [2]. On the other hand, however, the risk association between albuminuria and ESRD is linear across the full albuminuria range without evidence of a threshold [2].The lack of a threshold indicates that small increases in albuminuria, even within the normal range, (i.e. $<30 \mathrm{mg}$ albumin $\mathrm{g}^{-1}$ creatinine) confers clinical risk and necessitates clinical attention.

CKD is nowadays defined by a reduced glomerular filtration rate (GFR) and/or increased albuminuria [3]. Life expectancy substantially reduces when proteinuria levels increase or GFR levels decline. A study from Canada showed that patients aged 30 years with eGFR 30-44 and $15-29 \mathrm{ml} \mathrm{min}^{-1} 1.73 \mathrm{~m}^{-2}$ had a reduction in life expectancy of approximately 17 and 25 years, respectively, compared with those with normal kidney function (eGFR > 
$60 \mathrm{ml} \mathrm{min}{ }^{-1} 1.73 \mathrm{~m}^{-2}$ ) [4]. A reduction in life expectancy was also observed for patients with increasing levels of proteinuria. Subjects with mild or heavy proteinuria had a life expectancy that is reduced by approximately 10 and 18 years compared with subjects without proteinuria. These figures indicate that people with CKD require appropriate monitoring and proper therapy.

Significant progress has been made in the treatment of CKD in the past decades. Early detection of high risk patients in combination with increased secondary prevention efforts aimed at blood pressure, glycaemic and lipid control have improved the outlook of patients with CKD.

\section{Pharmacological intervention}

\section{State of the art treatment}

Current treatment of CKD is focused on optimizing renal and cardiovascular risk factors. The current treatment algorithm for CKD patients is based on the knowledge and experience of treating cardiovascular risk in general. Thus, it includes, next to lifestyle changes (dietary measures, stop smoking, exercise):

1 Control of high blood pressure

2 Control of albuminuria

3 Control of blood glucose

4 Control of blood lipids

However, the evidence for these therapies or strategies is not necessarily clear:

Treatment of high blood pressure is of paramount importance for preventing and delaying the progression of CKD. Blood pressure lowering therapy is vital during any stage of CKD and is the mainstay of renal (and cardiovascular) protective therapy. Agents that block the reninangiotensin-aldosterone-system (RAAS) are the first choice agents. The renoprotective effects of ACE inhibitors (ACEi) or angiotensin receptor blockers (ARB) are demonstrated in various studies in patients with different aetiologies of renal disease including diabetic nephropathy, hypertensive nephrosclerosis and various non-diabetic nephropathies [5-7]. A common finding in these studies is that the benefits of RAAS inhibiting drugs go beyond that expected from blood pressure lowering alone and are, to a large extent, explained by their anti-albuminuric effects [8-12].

Albuminuria lowering slows the progressive rate of renal function loss in patients with CKD and should therefore be considered a separate target for renoprotective therapy. The presence of albuminuria is not only a sign of renal impairment but it can also cause renal damage itself. Recent studies have shown that increased urinary albumin leakage stimulates inflammatory (e.g. monocyte chemotactic agent-1, RANTES) [13, 14], vasoactive (e.g. endothelin) and fibrotic (TGF- $\beta$, collagens) processes [15], causing interstitial damage ultimately leading to irreversible renal impairment. It is well known that RAAS blockade decreases albuminuria. As mentioned above, the benefits of RAAS blockade go beyond blood pressure lowering alone. In fact, studies in diabetic and nondiabetic patients with CKD have shown that the reduction in albuminuria during the first months of therapy is one of the strongest determinant of long term renoprotection $[11,16]$. RAAS blockade is not the only drug class that decreases albuminuria and affords renoprotection. Other interventions, such as a low protein diet [17], non-steroidal anti-inflammatory drugs [18] and corticosteroids [19], also decrease albuminuria and slow progression to ESRD.

Glucose lowering has been shown to prevent the development and progression of abnormal levels of albuminuria in people with diabetes. The Diabetes Control and Complication Trial (DCCT) showed that in 1441 patients with type 1 diabetes with no or mild retinopathy intensive glucose control with insulin injections reduced the risk of development of macroalbuminuria by $54 \%$ after a mean follow-up of 6.5 years [20]. At the end of the DCCT trial 1375 of these patients transitioned into the observational Epidemiology of Diabetes Interventions and Complications (EPIC) study. After 22 year follow-up of the combined DCCT/EPIC cohort eight patients in the intensive therapy group and 16 patients in the conventional therapy group developed ESRD (relative risk reduction 50\%) illustrating the benefit of early intensive glucose control in type 1 diabetes [21]. In patients with type 2 diabetes, a recent post hoc analysis from the ADVANCE trial determined whether intensive glucose lowering prevented or slowed the progression to ESRD. In the ADVANCE trial 11140 patients with type 2 diabetes with at least one risk factor for vascular disease were randomly allocated to a gliclazide based intensive glucose lowering therapy (aiming for a $\mathrm{HbA1c}$ target of $6.5 \%$ or less) vs. conventional glucose lowering therapy ( $\mathrm{HbA} 1 \mathrm{c}$ target defined by local guidelines). The study showed that intensive glucose lowering therapy protects against the development of ESRD, albeit that only 27 ESRD events were recorded during the trial [22]. Studies that are properly powered to assess the benefits of glycaemic control on hard renal outcomes are required to substantiate these findings.

Lipid lowering therapies have undoubtedly contributed to improved cardiovascular morbidity rates in the last decades. The cardiovascular benefits of lipid lowering are also observed in subjects with CKD. The SHARP trial demonstrated that the combination of simvastatin and ezetimibe conferred a $17 \%$ cardiovascular risk reduction in CKD [23]. The relative low reduction (compared with the cardiovascular protective effect of statin therapy in nonCKD patients) may be due to the fact that other factors than LDL-cholesterol contribute to cardiovascular risk in the CKD patient [24]. Further research is required to identify the causes of cardiovascular risk in these CKD patients 
and importantly to identify specific drug targets for further reduction of the high cardiovascular risk.

The renal protective effects of lipid lowering are not (yet?) definitively proven. Most lipid trials have involved subjects at cardiovascular risk and the number of ESRD events recorded in these trials is low. In SHARP a nonsignificant reduction of $7 \%(P=0.09)$ was observed in the incidence of doubling of serum creatinine or ESRD in subjects allocated to simvastatin/ezetimibe [23]. Whether the lack of renal benefits in SHARP specifically relates to the drug combinations used or whether it can be extrapolated to each lipid lowering agent is unknown. Based on the PLANET trials one could argue that different statins exert different renoprotective effects. The PLANET trial compared head-to-head atorvastatin $80 \mathrm{mg} \mathrm{day}^{-1}$ and rosuvastatin $10 \mathrm{mg} \mathrm{day}^{-1}$ and $40 \mathrm{mg} \mathrm{day}^{-1}$ in subjects with diabetic and non-diabetic CKD. Atorvastatin decreased proteinuria and did not appreciably change eGFR over time, while both doses of rosuvastatin did not decrease proteinuria and $40 \mathrm{mg} \mathrm{day}^{-1}$ rosuvastatin was associated with a significant fall in eGFR despite a similar (or even better) degree of cholesterol lowering [25]. Unfortunately, the PLANET trial did not include a placebo arm and thus a placebo-controlled comparison could not be made. Another randomized controlled trial assessed the antiproteinuric effect of fluvastatin in patients with chronic kidney disease who had proteinuira more than $0.5 \mathrm{~g} \mathrm{day}^{-1}$ despite receiving a combination of an ACEi and ARB. In that trial fluvastatin did not reduce proteinuria but further reduced serum lipids [26].These findings illustrate that different statins may have different effects on proteinuria and eGFR and suggest that the SHARP results may not be directly extrapolated to each statin. Results of other trials also point to a potential renoprotective effect of atorvastatin. In the ASCOT trial in 10305 subjects with hypertension and at least three cardiovascular risk factors, atorvastatin significantly improved eGFR over time compared with placebo treatment [27]. In addition, a recent meta-analysis involving more than 120000 patients showed that lipid lowering therapies attenuate the rate of progressive renal function loss over time from 0.87 to $0.67 \mathrm{ml} \mathrm{min}^{-1} 1.73 \mathrm{~m}^{-2}$ year $^{-1}$ [28]. Taken together, it seems that in general lipid lowering produces a modest decline in the rate of renal function loss but it may well be true that the degree of renoprotection depends on the off-target effect of the specific lipid lowering agent rather than being the result of the effect of cholesterol lowering per sé.

The above treatments by themselves or in combination have led to a considerable reduction in renal and cardiovascular risk in the CKD patient. However, despite the increased awareness of CKD and advances in the prevention of renal complications, there remains an enormous unmet need. This may be explained by the fact that the CKD patient runs an extremely high absolute risk for ESRD as well as cardiovascular morbidity and mortality, and the relatively small absolute risk reductions of proven therapies. Novel therapies to mitigate renal complications are therefore highly desirable. Table 1 provides an overview of novel intervention strategies for the prevention and treatment of CKD.

\section{Novel treatments and ongoing trials Targeting traditional risk factors}

Novel RAAS blockade strategies RAAS plays an important role in progressive organ function loss in CKD patients as highlighted by the results of several randomized controlled trials and meta-analyses demonstrating that inhibition of the RAAS with either ACEi or ARB affords renal and cardiovascular protection $[5,7,29,30]$. However, during single RAAS inhibition therapies (either ACEi or ARB) circulating RAAS remains fairly active. This has led to an expectation that enhancing RAAS blockade may provide greater protection against major adverse renal and cardiovascular outcomes. In analogy to effective diuretic treatments in which one combines blockade of systems at different crucial levels, the combination of ACEi and ARB was started, as well as recently ACEi or ARB with a direct renin inhibition (DRI). Indeed, dual therapy with both an ACEI and an $A R B$, or in combination with DRIs, has been shown to be more effective in reducing urinary albumin excretion and blood pressure than single agent therapy [31]. However, large scale randomized controlled trials have reported contradictory results. In the ONTARGET trial, in patients with established cardiovascular disease rather than kidney disease, dual blockade with the ACEi ramipril $\left(10 \mathrm{mg} \mathrm{day}^{-1}\right)$ and ARB (telmisartan $40 \mathrm{mg} \mathrm{day}^{-1}$ ) did not enhance cardiovascular protection [32]. In addition, dual blockade increased the risk for adverse renal outcomes compared with either monotherapy, in spite of better reduction of blood pressure and albuminuria [33]. It should be noted that most patients in the ONTARGET trial had urinary albumin concentrations in the normal range (i.e. had low renal risk) rendering the impact of dual blockade on renal end-points uncertain. The cardiovascular and renal protective effect of the combination of ACEi or ARB with a DRI (aliskiren) was tested in the ALTITUDE trial in diabetic patients who were selected for their high renal and cardiovascular risk profile. The safety monitoring board of the ALTITUDE trial recommended early trial termination, based on an interim analysis showing more cases of worsening of renal function, hyperkalaemia and increased risk of stroke. The final efficacy results confirmed the excess rate of adverse effects and provided definitive evidence of a lack of cardio-renal protection with aliskiren added to single RAAS blockade in patients with type 2 diabetes [34]. It has been suggested that dual agent RAAS blockade might be salutary in people with high albuminuria or low renal function. The Nephron-VA-D trial tested the combination of ACEi and ARB therapy on hard renal endpoints in patients with type 2 diabetes, macroalbuminuria and moderate to severe renal impairment (eGFR 30 to 


\section{Table 1}

Novel intervention strategies for the treatment of CKD

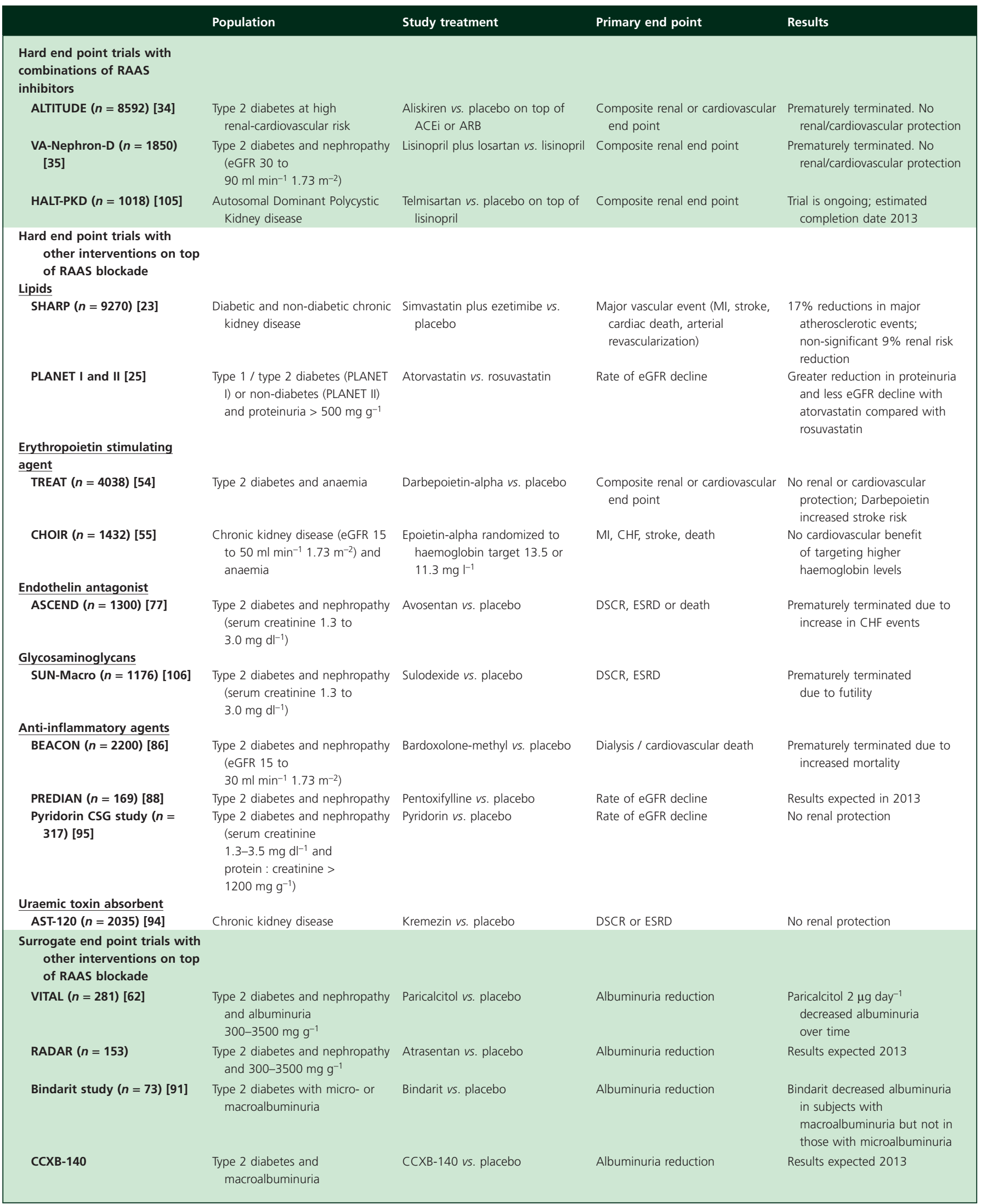

$\mathrm{CHF}$, congestive heart failure; DSCR, doubling of serum creatinine; ESRD, end-stage renal disease; MI, myocardial infarction. 
$90 \mathrm{ml} \mathrm{min}^{-1} 1.73 \mathrm{~m}^{-2}$ ) [35]. However, again the trial was prematurely discontinued because of severe hyperkalaemia and acute renal function loss in people allocated to dual agent RAAS blockade. Hence, in people with high albuminuria and renal impairment, dual RAAS blockade failed to afford renoprotection which casts major doubt on the efficacy and safety of dual RAAS blockade. All together, the lack of cardio-renal protection and excess rate of adverse events in three independent large clinical trials indicate that in general there is no place for dual RAAS blockade in the prevention and treatment of CKD. However, the response to RAAS blockade varies considerably among individuals and some patients show a marked reduction in blood pressure and albuminuria without developing hyperkalaemia or acute renal impairment. In such patients, dual RAAS blockade could be considered.

The mechanisms underlying the adverse outcomes of dual RAAS blockade are not fully established. Pharmacological effects are important to consider. The focus of RAAS blockade therapy is to improve blood pressure and albuminuria control, as it did in all of the above hard outcome trials. This view may thus be too narrow. RAAS blockade exerts a broad range of additional effects, i.e. on renal filtration pressure [36], potassium status [37], haemoglobin [38], uric acid [39] and inflammatory factors [40], all with prognostic impact. Since each of these parameters determines renal or cardiovascular risk, drug induced changes in these parameters will influence the ultimate renal or cardiovascular outcome, either favourably or harmful. It might be useful, therefore, to interpret drug effects on hard outcomes in terms of composite effects, rather than effects on blood pressure or albuminuria alone. For dual RAAS blockade, theoretically, the balance may tilt to harm (for instance by inducing hyperkalaemia or inducing hypotension) in patients in whom effects on blood pressure or albuminuria are relatively trivial. Further studies on the response profiles for multiple parameters in individual patients are necessary to clarify to what extent such mechanisms are indeed at play.

A lot of attention has been paid to mineralocorticoid receptor antagonists (MRAs) since the publication of the first study demonstrating that the MRA spironolactone decreases proteinuria in CKD subjects [41]. Numerous experimental and clinical studies followed and confirmed the profound anti-albuminuric effects of MRAs [42-44]. These beneficial effects render MRAs promising drugs for the prevention of ESRD and cardiovascular morbidity and mortality in patients with nephropathy. However, in particular in the population with CKD, the use of MRAs is limited by the risk of development of life-threatening hyperkalaemia, which is the consequence of the potassium-sparing properties of these agents in low filtration conditions. The risk of hyperkalaemia clearly restricts the widespread application of MRA therapy among CKD patients. Nevertheless several possibilities exist to prevent or control hyperkalaemia as recently reviewed by Roscioni
[45]. These measures include limiting potassium rich food consumption, discontinuation of drugs that impair potassium excretion (e.g. non-steroidal anti-inflammatory drugs) or prescribing potassium binders. With respect to the latter, a new non-absorbable polymer (RLY5016) designed to bind potassium in the gastro-intestinal tract was recently tested in patients with heart failure receiving spironolactone treatment. The results indicated that this polymer caused significant reductions in serum potassium, prevented hyperkalaemia, and was well tolerated [46]. Long term studies are needed to assess the long term safety of this therapy. In addition, novel MRAs are currently in development with high affinity and selectivity for the MR receptor, such as BR4628 and SM368229 [47, 48]. Preclinical studies have shown that these drugs exert powerful anti-albuminuric effects but have limited effect on plasma potassium concentrations. Clinical studies are ongoing to characterize the dissociation between the antialbuminuric effects and potassium-sparing effects of these agents in humans.

Glycaemic control Dipeptidylpeptidase inhibitors are a new class of hypoglycaemic drugs. DPP-IV inhibitors inhibit the degradation of glucagon-like peptide -1 (GLP-1). By inhibiting the degradation of GLP-1 these agents enhance insulin secretion in the pancreas and reduces glucagon release, resulting in a reduction in fasting plasma glucose and $\mathrm{HbA} 1 \mathrm{c}$. Various DPP-IV inhibitors are available for clinical use such as sitagliptin, saxagliptin and linagliptin. The HbA1c lowering effects of the various DPP-IV inhibitors seem to be comparable. However, the pharmacokinetic properties vary among the different agents which could render a specific agent particularly useful for a certain subpopulation. For example, linagliptin is mainly metabolized and eliminated by the liver. No dose adjustments are required for patients with impaired kidney function which makes linagliptin particularly attractive for the patient with diabetes and nephropathy. Whether DPP-IV inhibitors delay the progression towards ESRD is unknown but some studies support a potential renoprotective effect. Sitagliptin has been shown to decrease albuminuria by $20 \%$ in a prospective observational study [49]. More recently, a meta-analysis of 13 randomized controlled trials involving nearly 5500 individuals demonstrated that linagliptin causes a $16 \%(95 \% \mathrm{Cl} 3,28 \%, P<0.05)$ reduction in a composite renal end point consisting of micro- or macro-albuminuria, loss of eGFR $>50 \%$ from baseline, acute renal failure or death [50]. Future long term controlled trials are warranted to confirm these findings.

Sodium-glucose transport inhibition is another new target to achieve glycaemic control. SGLT2 inhibitors reversely inhibit the SGLT-2 transporter which is located in the proximal tubule. The SGLT-2 transporter is responsible for the nearly complete reabsorption of glucose in order to maintain appropriate glucose concentrations (under 
Novel interventions for the treatment of chronic kidney disease $\mathrm{B}] \mathrm{CP}$

normal physiologic circumstances). Treatment with SGLT-2 inhibitors increases urinary glucose excretion and decreases fasting plasma glucose and HbA1c [51]. Apart from their effect on metabolic parameters, SGLT-2 inhibitors also decrease blood pressure, body weight and albuminuria [51]. Large clinical outcome trials with the SGLT-2 inhibitors dapagliflozin, (NCT01730534) canagliflozin, (NCT01032629) and empagliflozin (NCT01131676) are ongoing to characterize the long term renal and cardiovascular protective efficacy and safety of this new drug class.

\section{Targeting kidney related risk factors}

Erythropoetin stimulating agents Observational studies have suggested that anaemia is another risk marker of renal and cardiovascular disease next to and independent of blood pressure, hyperglycaemia and hypercholesterolaemia. Earlier studies with erythropoietin stimulating agents have shown that in patients with severe anaemia, increasing haemoglobin markedly increased quality of life and reduced requirements of blood transfusions $[52,53]$. These convincing results led to the general believe that increasing haemoglobin levels would decrease the risk of renal and cardiovascular disease and resulted in the widespread use of these agents. However, recent randomized clinical trials documented that treating low haemoglobin levels to targets above $13.0 \mathrm{~g} \mathrm{dl}^{-1}$ in diabetic or $13.5 \mathrm{~g} \mathrm{dl}^{-1}$ in non-diabetic CKD did not decrease the incidence of renal or cardiovascular events $[54,55]$. These results tempered the promise that early correction of anaemia delays renal disease progression. Again, this may not be due to the fact that correction of anaemia would not result in renal and/or cardiovascular protection, but the drugs and or the dose of the drugs used to correct anaemia, may induce other (negative) effects that offset a potential renal cardiovascular protection. Indeed, it was shown in TREAT study that the harmful effects were particularly observed in the group of patients who needed high darbepoeietin- $\alpha$, the so-called non-responders [56]. The results of the TREAT and CHOIR trials are now translated in treatment guidelines which recommend not to intentionally target haemoglobin to levels above $115 \mathrm{~g} \mathrm{l}^{-1}$ $\left(11.5 \mathrm{~g} \mathrm{dl}^{-1}\right)$ [57].

Vitamin D Emerging data suggest that vitamin D plays a vital role in renal and cardiovascular health. People with CKD have lower vitamin D concentrations than healthy individuals and observational studies have demonstrated that CKD patients treated with vitamin $D$ receptor activators have a survival benefit compared with untreated patients [58]. Several studies have reported that vitamin D receptor activators decrease albuminuria in both diabetic and non-diabetic nephropathy [59-61]. The largest study in this respect was the VITAL study. The results showed that paricalcitol in addition to ACEi or ARB therapy appears to reduce albuminuria in a dose-dependent fashion and was well tolerated [62]. Whether vitamin $\mathrm{D}$ activators delay the progression to ESRD is not investigated and needs to be proven. A large clinical trial in 20000 people with evidence of heart disease is currently ongoing investigating whether vitamin $D$ supplementation (cholecalciferol) or omega-3 fatty acids reduces the risk of developing cancer, heart disease and stroke (NCT 01169259). The effects of vitamin $\mathrm{D}$ or fish oil on kidney disease progression will be assessed as well (http://www.vitalstudy.org).

Phosphate Control of serum phosphate by restricting dietary phosphate or phosphate binders has been a mainstay in the treatment of CKD to manage bone disease for many years. However, recent observational studies link high serum phosphate to accelerated progressive renal function loss and cardiovascular disease [63]. In addition, emerging data demonstrate that fibroblast growth factor23, a phosphaturic hormone, is elevated in early CKD and linked with renal and cardiovascular outcomes, suggesting a pathophysiological role of impaired phosphate control in the onset and progression of CKD. Intervention trials to test the efficacy of phosphate-lowering strategies on hard renal or cardiovascular end points are lacking but are clearly warranted.

Uric acid A number of studies have shown that uric acid predicts the progression of renal function loss in diabetic and non-diabetic CKD [64, 65]. Uric acid is generated during the metabolism of nucleotides and represents the end product of purine metabolism. Uric acid appears to have a broad range of adverse effects including activation of pro-inflammatory pathways resulting in increased synthesis of chemokines and inflammatory markers [66], decreasing the bioavailability of nitric oxide leading to endothelial dysfunction [67] and activation of systematic and intra-renal RAAS [68]. These pathogenic effects of uric acid in combination with the independent association between uric acid and renal and cardiovascular outcome raise the possibility that interventions that reduce uric acid may afford renal (and cardiovascular) protection. A small prospective intervention study involving 113 subjects with CKD of mixed aetiology reported that allopurinol caused a mean increase in eGFR of $1.3 \mathrm{ml} \mathrm{min} \mathrm{m}^{-1} 1.73 \mathrm{~m}^{-2}$ whereas in the placebo group eGFR fell by $3.3 \mathrm{ml} \mathrm{min}^{-1} 1.73 \mathrm{~m}^{-2}$ over the 24 months follow-up period [69]. Febuxostat is a nonpurine selective xanthine oxidase inhibitor and is approved for use in patients with hyperuricaemia and gout. An analysis of a 5 year open label trial in 116 patients treated with febuxostat demonstrated an inverse correlation between serum uric acid reduction and rate of eGFR decline so that individuals with the greatest reduction in serum uric acid following febuxostat treatment experienced the slowest rate renal function decline [70]. Finally, a meta-analysis, involving 11 clinical trials and 753 participants, found that urate lowering therapy decreased serum creatinine and increased eGFR suggesting that urate 
lowering therapy may have beneficial effects on delaying the progression of renal disease [71]. These small scale studies and the meta-analysis support the conduct of a large confirmatory trial specifically designed to determine the renoprotective effects of urate lowering therapies.

\section{Targeting novel risk factors}

Endothelin antagonists The endothelin system is chronically activated in patients with nephropathy. Binding of endothelin to the endothelin type $A$ receptor $\left(E T_{A}\right.$ receptor) elicits pronounced vasoconstriction, sodium retention, and promotes podocyte dysfunction leading to glomerular damage, proteinuria and renal function loss [72, 73]. In contrast, endothelin type B receptor activation causes vasodilatation and sodium excretion. Specific blockade of the $\mathrm{ET}_{\mathrm{A}}$ receptor, may thus be a promising target to ameliorate renal complications. Intriguingly, endothelin seems to interact with tubular proteins thereby promoting renal fibrosis. It has been shown that exposure of tubular cells to increasing amounts of albumin causes a dose-dependent increase in the generation of endothelin-1 [74]. Endothelin-1 mediates secretion of proinflammatory cytokines and growth factors, such as TGF- $\beta$, which contribute to interstitial remodelling and scarring $[75,76]$.

Avosentan, an endothelin receptor blocker, significantly reduced proteinuria in patients with type 2 diabetes and nephropathy. However, a large phase 3 trial, testing the effect of avosentan on hard renal outcomes (ASCEND), was terminated prematurely because of an excess of congestive heart failure (CHF) and mortality in the avosentan treatment arm [77]. The excess number of CHF events observed in the ASCEND trial may be due to the highdoses of avosentan and the lack of specific investigator guidelines to prevent or treat sodium and fluid retention. A recent post hoc analysis of the ASCEND trial showed that the rise in body weight during avosentan therapy serves as an early risk marker for the development of CHF events [78]. Thus, another hard outcome trial was prematurely terminated. In this case the drug had again the expected effect on the surrogate marker (proteinuria) but had simultaneously detrimental effects (in this case tubular sodium handling) which led to an excess of CHF events.

Recently, more specific $\mathrm{ET}_{\mathrm{A}}$ receptor antagonists than avosentan, such as sitaxsentan and atrasentan, became available for clinical research. The higher selectivity of these agents for the $\mathrm{ET}_{\mathrm{A}}$ receptor could theoretically mean that adverse events related to fluid overload and oedema are less likely to happen. A recent study with sitaxsentan in patients with CKD showed that sitaxsentan decreased blood pressure and proteinuria and had favourable effects on various other renal and cardiovascular biomarkers including pulse wave velocity, uric acid and asymmetric dimethylarginine (ADMA) [79]. The proteinuria lowering in this study was modest ( $25 \%$ reduction) as compared with the effects of atrasentan in patients with diabetic nephropathy. In a randomized controlled double-blind trial in 89 subjects who were on stable doses of ACEi or ARB treatment with atrasentan for 8 weeks resulted in significant reductions in albuminuria from baseline for subjects receiving $0.75 \mathrm{mg} \mathrm{day}^{-1}$ atrasentan $(42 \%$ reduction, $P=$ 0.023 ) and $1.75 \mathrm{mg} \mathrm{day}^{-1}$ (36\% reduction, $P=0.073$ ) compared with placebo (11\% reduction) [80]. The larger RADAR trial, which is currently ongoing (NCT01356849), will further characterize the efficacy and safety of atrasentan in patients with diabetes and nephropathy.

Anti-inflammatory agents The risk factors that cause cardiovascular and renal morbidity and mortality such as high blood pressure and albuminuria involve a pathophysiological mechanism of which low grade inflammation makes up an important part. Indeed mounting evidence supports a key role of inflammation in the progression of CKD. In recent years many novel inflammatory markers have been identified. The discovery of these inflammatory molecules may provide novel insight into therapeutic targets for pharmacological intervention. Various randomized controlled trials have been conducted or are ongoing targeting inflammatory pathways. The majority of these trials focus on diabetic nephropathy most likely because inflammatory molecules are typically elevated in patients with diabetes and inflammation and subsequent extracellular matrix expansion is a common pathway of renal damage in diabetes.

Bardoxolone Bardoxolone-methyl is an anti-oxidative and anti-inflammatory drug which activates the nuclear factor-erythroid-2-related factor (Nrf2)-Keap1 pathway. Nrf2 regulates the induction of multiple antioxidant genes. As such, it exerts anti-oxidative and anti-inflammatory effects and thus serves as a defense factor against kidney injury [81-83]. In a previous non-randomized 8 week trial, treatment with bardoxolone-methyl resulted in a significant increase in eGFR in patients with type 2 diabetes and CKD stage 3 or 4 [84]. A subsequent 52 week follow-up study showed that the early bardoxolone-methyl-induced rise in eGFR was sustained throughout the 52 week follow-up period [85]. These promising results led to the initiation of the BEACON trial which was designed to assess whether bardoxolone-methyl decreases the incidence of dialysis and can be safely used in patients with type 2 diabetes and nephropathy [86]. The Data Safety Monitoring Board recommended however early trial termination due to excess mortality in the bardoxolone-methyl treatment arm (http://www.reatapharma.com). Analyses are ongoing to elucidate these unexpected results.

Pentoxifylline Pentoxifylline is a methyl xanthine derivative that acts in vivo as a phosphodiesterase inhibitor. A number of clinical studies have shown the antialbuminuric properties of pentoxifylline and a combined meta-analysis of these trials documented that oral 
pentoxifylline reduced albuminuria by nearly $300 \mathrm{mg}^{\text {day }}{ }^{-1}$ vs. control therapy [87]. The effect of pentoxifylline on the progression of renal function decline is not (yet) established but currently under investigation in the ongoing Pentoxifylline for Renoprotection in Diabetic Nephropathy (PREDIAN) trial [88]. The results of this trial are expected in 2013.

CTP-499 CTP-499 is an active metabolite of pentoxifylline. CTP-499 is under development based on previous studies showing anti-albuminuric effects of pentoxifylline. CTP-499 is thought to have an improved metabolic profile. Specifically, a pre-clinical study has shown that CTP-499 possesses anti-inflammatory, antifibrotic and anti-oxidant properties [89]. A 24 week phase 2 randomized placebo controlled trial is currently ongoing to assess whether CTP-499 exerts anti-albuminuric effects in 170 patients with type 2 diabetes and nephropathy (NCT01487109).

Monocyte chemoattractant protein-1 inhibition Monocyte chemoattractant protein-1 (MCP-1), a potent cytokine, plays a key role in initiating and sustaining chronic inflammation in renal tissues. MCP-1 is secreted in response to high glucose concentrations. MCP-1 promotes monocytes and macrophage activation and activates other pro-inflammatory cytokines. Urinary MCP-1 concentrations correlate with the degree of albuminuria in patients with diabetes and interestingly the reduction of albuminuria induced by ACEi correlates with the degree of urinary MCP-1 reduction [90]. These findings support the idea that inhibition of MCP-1 reduces albuminuria and improves long term renal function. A prospective randomized controlled study showed that pharmacological inhibition of MCP-1 synthesis reduced albuminuria on top of ACEi or ARB therapy relative to placebo in subjects with type 2 diabetes and macroalbuminuria but it did not change albuminuria in subjects with microalbuminuria [91]. To our knowledge no hard renal outcome trials are ongoing.

MCP-1 is a ligand for the C-C chemokine receptor 2 (CCR2). CCR2 is found on monocytes and macrophages and involved in initiating and sustaining inflammation. Blockade of the CCR2-receptor is another strategy to inhibit the detrimental effects of MCP-1.Pre-clinical studies have shown that the CCR2 antagonist CCX140 reduces albuminuria in a mouse model of diabetic nephropathy [92]. A phase 2 clinical study is currently ongoing to evaluate the anti-albuminuric effects of CCX140 in patients with type 2 diabetes and macroalbuminuria (NCT01440257). Results of this study are expected in 2013.

Uraemic toxin absorbants Kremezin (AST-120) is a charcoal agent that absorbs uraemic toxins, such as indoxyl sulphate and methylguanidine, in the gastro-intestinal tract. In addition, AST-120 inhibited TGF- $\beta$ in animal models of diabetic nephropathy [93]. AST-120 has been mainly studied in Asian countries and small clinical studies have suggested that AST-120 retards renal disease progression. Kremezin was approved in Japan in 1991 for prolonging the time to dialysis and improving uraemic symptoms. Two randomized placebo controlled trials (EPPIC1/EPPIC2) were recently completed involving in total 2035 subjects with CKD from Europe or the United States. The combined analysis showed that krezemin did not afford renal protection and $35 \%$ and $36 \%$ of subjects in the kremezin and placebo arms, respectively, reached the primary end point of ESRD or doubling of serum creatinine [94].

Vitamin B therapy Pyridoxamine is a metabolic derivative of vitamin $B_{6}$ and inhibits the formation of advanced glycation end products (AGE). AGEs are formed in hyperglycaemic milieus through a chemical reaction of a glucose molecule with a $\mathrm{NH}_{2}$ end product of a protein which in turn becomes glycosolated. AGE formation has a direct pathological effect in the kidney resulting in thickening glomerular basement membrane trough expansion of the extracellular matrix. A recent clinical trial was designed to test the hypothesis whether pyridoxamine delayed the progressive renal function loss in patients with type 2 diabetes, nephropathy and marked proteinuria. The results showed no difference in the rate of renal function decline between pyridoxamine and placebo treated patients, although a post hoc analysis suggested that pyridoxamine may delay the loss of renal function in subjects with the lowest serum creatinine concentrations at baseline [95]. Other B vitamins have also not been successful in halting the progression of renal disease or reducing urinary albumin excretion rates [96]. In fact, a multicentre clinical trial of high dose vitamin B therapy (vitamin B6, B12 and folic acid) showed a three-fold increase in the rate of renal function loss and a two-fold increase in the risk of cardiovascular disease [97].

It is important to note that most of the trials conducted so far with anti-inflammatory agents (with the exception of the BEACON and EPPIC trials) involved less than 300 patients and have only evaluated the effects on surrogate end points of renal disease progression. Although the results of some of these trials look promising they have to be confirmed in large hard outcome trials.

\section{Innovative treatment strategies}

\section{Multiple risk marker targeting}

The vast majority of intervention trials target a single risk factor (e.g. blood pressure or $\mathrm{HbA1c}$ ). A multi-factorial approach simultaneously targeting the various pathways involved in the pathogenesis of CKD may lead to more salutary long term outcomes. A formal multifactorial intervention trial aimed at behavioural modifications, (smoking 


\section{Table 2}

On-target and off-target effects of various drugs used in the management of CKD

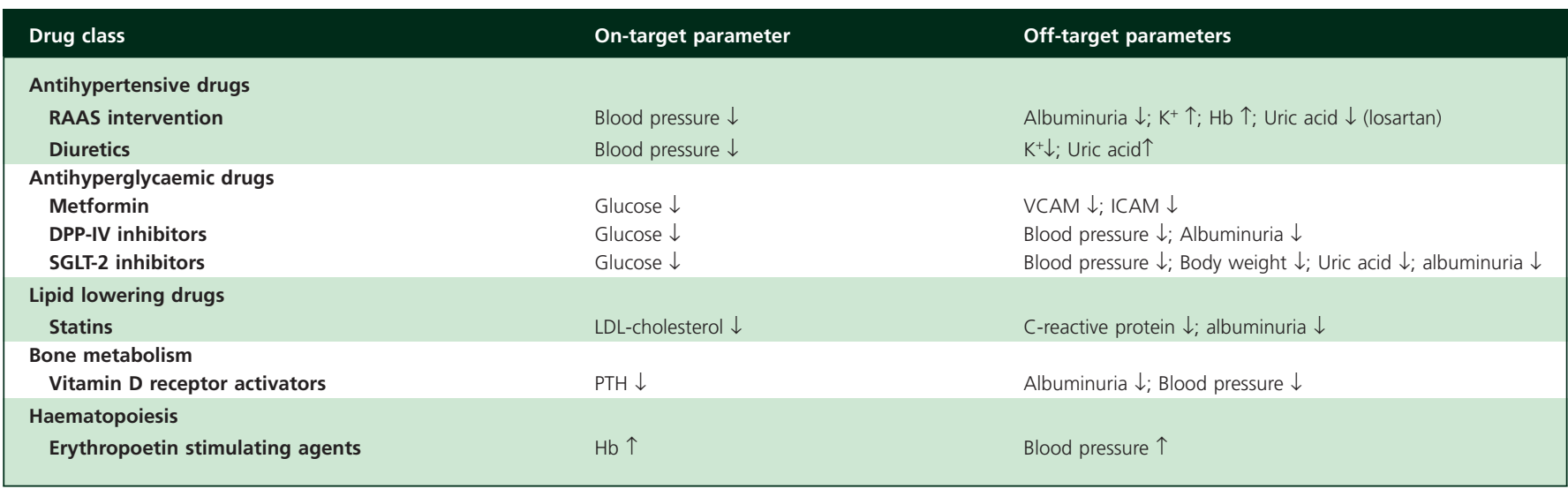

Hb, haemoglobin; HDL, high-density lipoprotein; ICAM, intercellular cell adhesion molecule; K+, potassium; LDL, low-density lipoprotein; VCAM, vascular cell adhesion molecule.

cessation and diet changes) and intensive blood pressure, lipids, glucose and body weight control vs. conventional therapy has been conducted in patients with diabetes. The results demonstrate that an intensive multi-factorial treatment approach causes a nearly $50 \%$ relative renal and cardiovascular risk reduction [98]. A similar multifactorial treatment programme consisting of lifestyle modification and optimal risk factor control has been implemented in proteinuric CKD patients. Interestingly, patients who participated in that multifactorial treatment programme had a nearly four-fold reduction in eGFR decline compared with matched controls who received ACEi therapy titrated to optimal blood pressure control [99]. These results undoubtedly support the implementation of integrated multifactorial treatment approaches aimed at improving lifestyle behaviour and optimal risk factor control.

\section{Optimizing personalized therapy}

In spite of the proven efficacy of renoprotective interventions, mainly single RAAS blockade and glycaemic control in diabetes, at a group level the long term protective effects of these interventions show a marked heterogeneity between individual patients. For example, the renoprotective effects of ACEi or ARB have been convincingly shown in large randomized controlled trials. Yet, at the individual level, the effects of these agents range from a complete arrest of renal function loss to no beneficial effects or even harm in some patients. Insight into the marked inter-individual heterogeneity in treatment response may provide clues to optimize the treatment for the individual. With respect to ACEi and ARB, it has been shown that genetic factors [100], dietary factors [101], obesity [102] and the type and severity of renal disease [103] modulate the efficacy of these agents.

The marked heterogeneity between individuals in long term drug effects may also be explained by the variability in drug response in multiple parameters within an individual (so called intra-individual variability). It is known that single drugs affect multiple parameters next to the parameter the drug is developed and targeted to. Many of these so-called off-target parameters also beneficially or adversely affect long term renal outcome. Examples of on-target and off-target parameters of drugs used in the management of CKD patients are shown in Table 2. These on-target and off-target responses in multiple parameters to a single drug differ per individual. This constitutes so called discordance in response. For example, ARB may lower blood pressure, lower albuminuria and/or increase serum potassium. The response in these parameters is discordant within individual patients [104]. This suggests that the composite effect of a drug on multiple parameters (blood pressure, albuminuria, serum potassium etc) in individual patients should be determined and be optimized to improve the ultimate effect on clinical outcomes. Prospective trials are needed to validate this concept.

\section{Summary and future perspectives}

Given the large number of drugs that failed to afford reno(cardiac-) protection in the last 5 years it seems impossible to develop new drugs for the management of CKD. One could conclude that it would be better to stop investing money and effort into developing new treatments for CKD. Before drawing such conclusions we believe that we should first identify the underlying reasons why so many drugs failed in the late stage of drug development.

From Table 1 it becomes clear that many trials failed due to severe adverse side effects. The severity and frequency of these adverse effects and their impact on the main study outcome were unexpected, in particular because the drugs under development had shown 
Novel interventions for the treatment of chronic kidney disease

favourable effects on renal and cardiovascular risk factors, such as blood pressure, cholesterol or proteinuria, so-called on-target risk markers. Thus, the drugs did not deliver what could be anticipated based on their beneficial effects on the renal and cardiovascular risk markers. As highlighted throughout this review, the explanation for the failure of many drugs appears to be that the drugs exerted effects on multiple other risk markers, so called off-target effects. Many of these drug effects on off-target risk markers have beneficial or adverse effects on the long term renal or cardiovascular outcome. In the case of adverse effects, they offset the beneficial on-target risk marker effect. Hence, to estimate drug effects based on changes in renal or cardiovascular risk markers one should not only focus on the on-target risk marker but integrate all drug induced risk marker changes. Such an approach of drug efficacy (and safety) estimation based on multiple risk markers has at least two implications. First, drug effects on all potential renal or cardiovascular risk markers should be carefully examined already in early clinical drug development. This means rigorous measurement and monitoring of all drug effects, not only the on-target drug effect. Second, if offtarget effects exist that could blunt the protective treatment effect, management protocols should be developed and applied to prevent or minimize off-target effects in vulnerable patients. For example, an endothelin antagonist may increase fluid retention in some patients. Changes in body weight should be closely monitored to identify individuals who may experience fluid retention. Subsequently, in patients with body weight increases, treatment with diuretics should be started to reverse the fluid retaining effects, or patients should discontinue the drug. The same could be imagined when applying drugs or drug combinations that induce a rise in serum potassium. This should lead to measures to control serum potsassium and if not successful withdrawal of therapy. In doing so, the harmful off-target effects are minimized and the overall drug effect is maximized.

\section{Conclusion}

Despite the successful use of lifestyle changes, metabolic control and blood pressure control including ACEi and ARB therapy, the residual renal and cardiovascular risk in patients with CKD remains very high, leaving them with a clear unmet need. Novel treatment strategies are imperative to improve the prognosis of these patients. As outlined in this review, various drugs are in the pipeline that may offer additional renoprotection and have the potential to reduce the high morbidity and mortality. However, we have to be vigilant for off-target effects that may counteract the beneficial promising effects of these novel drugs. Confirmatory hard outcome trials should therefore be designed in such a way that all off-target effects are closely monitored and managed in order to avoid more drug failures in the future.

\section{Competing Interests}

Both authors have completed the Unified Competing Interest form at http://www.icmje.org/coi_disclosure.pdf (available on request from the corresponding author) and declare HJLH and DdZ had no support for the submitted work. HJLH has financial relationships (consultancy agreements) with any of the following organizations that might have an interest in the submitted work in the previous 3 years: Abbvie, Astellas, Johnson \& Johnson, Reata Pharmaceuticals and Vitae. All honoraria are paid to his institution. DdZ has consultancy agreements with the following companies: Abbvie, Astellas, Bristol-Meyers Squibb, Hemocue, Johnson \& Johnson, Merck Sharpe \& Dohme, Novartis, Reata Pharmaceuticals and Vitae. All honoraria are paid to his institution. HJLH and DdZ are employed by University of Groningen, University Medical Center of Groningen and have no other relationships or activities that could appear to have influenced the submitted work.

H.J. Lambers Heerspink is supported by a VENI-Grant from the Netherlands Organization for Scientific Research.

\section{REFERENCES}

1 Dor A, Pauly MV, Eichleay MA, Held PJ. End-stage renal disease and economic incentives: the International Study of Health Care Organization and Financing (ISHCOF). Int J Health Care Finance Econ 2007; 7: 73-111.

2 Gansevoort RT, Matsushita K, van der Velde M, Astor BC, Woodward M, Levey AS, de Jong PE, Coresh J. Lower estimated GFR and higher albuminuria are associated with adverse kidney outcomes. A collaborative meta-analysis of general and high-risk population cohorts. Kidney Int 2011; 80: 93-104.

3 Levey AS, de Jong PE, Coresh J, El Nahas M, Astor BC, Matsushita K, Gansevoort RT, Kasiske BL, Eckardt KU. The definition, classification, and prognosis of chronic kidney disease: a KDIGO Controversies Conference report. Kidney Int 2011; 80: 17-28.

4 Gansevoort R, Correa-Rotter R, Hemmelgarn B, Jafar TH, Lambers Heerspink HJ, Mann JF, Matsushita K, Wen CP. Chronic kidney disease amplifies cardiovascular risk: impact, mechanisms and prevention. Lancet 2013; 382: 339-52.

5 Brenner BM, Cooper ME, de Zeeuw D, Keane WF, Mitch WE, Parving HH, Remuzzi G, Snapinn SM, Zhang Z, Shahinfar S. Effects of losartan on renal and cardiovascular outcomes in patients with type 2 diabetes and nephropathy. N Engl J Med 2001; 345: 861-9.

6 Agodoa LY, Appel L, Bakris GL, Beck G, Bourgoignie J, Briggs JP, Charleston J, Cheek D, Cleveland W, Douglas JG, Douglas 
M, Dowie D, Faulkner M, Gabriel A, Gassman J, Greene T, Hall Y, Hebert L, Hiremath L, Jamerson K, Johnson CJ, Kopple J, Kusek J, Lash J, Lea J, Lewis JB, Lipkowitz M, Massry S, Middleton J, Miller ER, 3rd, Norris K, O'Connor D, Ojo A, Phillips RA, Pogue V, Rahman M, Randall OS, Rostand S, Schulman G, Smith W, Thornley-Brown D, Tisher CC, Toto $\mathrm{RD}$, Wright JT, Jr, Xu S. Effect of ramipril vs. amlodipine on renal outcomes in hypertensive nephrosclerosis: a randomized controlled trial. JAMA 2001; 285: 2719-28.

7 Randomised placebo-controlled trial of effect of ramipril on decline in glomerular filtration rate and risk of terminal renal failure in proteinuric, non-diabetic nephropathy. The GISEN Group (Gruppo Italiano di Studi Epidemiologici in Nefrologia). Lancet 1997; 349: 1857-63.

8 Jafar TH, Stark PC, Schmid CH, Landa M, Maschio G, Marcantoni C, de Jong PE, de Zeeuw D, Shahinfar S, Ruggenenti P, Remuzzi G, Levey AS. Proteinuria as a modifiable risk factor for the progression of non-diabetic renal disease. Kidney Int 2001; 60: 1131-40.

9 Lea J, Greene T, Hebert L, Lipkowitz M, Massry S, Middleton J, Rostand SG, Miller E, Smith W, Bakris GL. The relationship between magnitude of proteinuria reduction and risk of end-stage renal disease: results of the African American study of kidney disease and hypertension. Arch Intern Med 2005; 165: 947-53.

10 Ruggenenti P, Perna A, Remuzzi G. Retarding progression of chronic renal disease: the neglected issue of residual proteinuria. Kidney Int 2003; 63: 2254-61.

11 de Zeeuw D, Remuzzi G, Parving HH, Keane WF, Zhang Z, Shahinfar S, Snapinn S, Cooper ME, Mitch WE, Brenner BM. Proteinuria, a target for renoprotection in patients with type 2 diabetic nephropathy: lessons from RENAAL. Kidney Int 2004; 65: 2309-20.

12 Holtkamp FA, De Zeeuw D, De Graeff PA, Laverman GD, Berl T, Remuzzi G, Packham DK, Lewis JB, Parving HH, Lambers Heerspink HJ. Albuminuria and blood pressure, independent targets for cardioprotective therapy in patients with diabetes and nephropathy; a post hoc analysis of the combined RENAAL and IDNT trials. Eur Heart J 2011; 32: 1493-9.

13 Wang Y, Chen J, Chen L, Tay YC, Rangan GK, Harris DC. Induction of monocyte chemoattractant protein-1 in proximal tubule cells by urinary protein. J Am Soc Nephrol 1997; 8: 1537-45.

14 Zoja C, Donadelli R, Colleoni S, Figliuzzi M, Bonazzola S, Morigi M, Remuzzi G. Protein overload stimulates RANTES production by proximal tubular cells depending on NF-kappa B activation. Kidney Int 1998; 53: 1608-15.

15 Wohlfarth V, Drumm K, Mildenberger S, Freudinger R, Gekle M. Protein uptake disturbs collagen homeostasis in proximal tubule-derived cells. Kidney Int Suppl 2003; 84: S103-9.

16 Hou FF, Xie D, Zhang X, Chen PY, Zhang WR, Liang M, Guo ZJ, Jiang JP. Renoprotection of Optimal Antiproteinuric Doses (ROAD) Study: a randomized controlled study of benazepril and losartan in chronic renal insufficiency. J Am Soc Nephrol 2007; 18: 1889-98.
17 Levey AS, Greene T, Beck GJ, Caggiula AW, Kusek JW, Hunsicker LG, Klahr S. Dietary protein restriction and the progression of chronic renal disease: what have all of the results of the MDRD study shown? Modification of Diet in Renal Disease Study group. J Am Soc Nephrol 1999; 10: 2426-39.

18 Vriesendorp R, Donker AJ, de Zeeuw D, de Jong PE, van der Hem GK, Brentjens JR. Effects of non-steroidal anti-inflammatory drugs on proteinuria. Am J Med 1986; 81: 84-94.

19 Lv J, Xu D, Perkovic V, Ma X, Johnson DW, Woodward M, Levin $\mathrm{A}$, Zhang $\mathrm{H}$, Wang $\mathrm{H}$. Corticosteroid therapy in IgA nephropathy. J Am Soc Nephrol 2012; 23: 1108-16.

20 DCCT_Research_Group. The effect of intensive treatment of diabetes on the development and progression of long-term complications in insulin-dependent diabetes mellitus. The Diabetes Control and Complications Trial Research Group. N Engl J Med 1993; 329: 977-86.

21 de Boer IH, Sun W, Cleary PA, Lachin JM, Molitch ME, Steffes MW, Zinman B. Intensive diabetes therapy and glomerular filtration rate in type 1 diabetes. $N$ Engl J Med 2011; 365: 2366-76.

22 Perkovic V, Heerspink HL, Chalmers J, Woodward M, Jun M, Li Q, Macmahon S, Cooper ME, Hamet P, Marre M, Mogensen CE, Poulter N, Mancia G, Cass A, Patel A, Zoungas $\mathrm{S}$. Intensive glucose control improves kidney outcomes in patients with type 2 diabetes. Kidney Int 2013; 83: 517-23.

23 Baigent C, Landray MJ, Reith C, Emberson J, Wheeler DC, Tomson C, Wanner C, Krane V, Cass A, Craig J, Neal B, Jiang L, Hooi LS, Levin A, Agodoa L, Gaziano M, Kasiske B, Walker R, Massy ZA, Feldt-Rasmussen B, Krairittichai $U$, Ophascharoensuk V, Fellstrom B, Holdaas H, Tesar V, Wiecek A, Grobbee D, de Zeeuw D, Gronhagen-Riska C, Dasgupta T, Lewis D, Herrington W, Mafham M, Majoni W, Wallendszus K, Grimm R, Pedersen T, Tobert J, Armitage J, Baxter A, Bray C, Chen Y, Chen Z, Hill M, Knott C, Parish S, Simpson D, Sleight $P$, Young A, Collins R. The effects of lowering LDL cholesterol with simvastatin plus ezetimibe in patients with chronic kidney disease (Study of Heart and Renal Protection): a randomised placebo-controlled trial. Lancet 2011; 377: 2181-92.

24 Massy ZA, De Zeeuw DLD. L-cholesterol in CKD to treat or not to treat? Kidney Int 2013; doi: 10.1038/ki.2013.181.

25 de Zeeuw D, Anzalone D, Cain V, Cressman M, Molitoris B, Monyak J, Parving $\mathrm{HH}$. Different renal protective effects of atorvastatin and rosuvastatin in patients with proteinuric diabetic and non-diabetic renal disease; result from the PLANET trials. ERA-EDTA conference, Munich, Germany 2010.

26 Ruggenenti P, Perna A, Tonelli M, Loriga G, Motterlini N, Rubis N, Ledda F, Rota S, Jr, Satta A, Granata A, Battaglia G, Cambareri F, David S, Gaspari F, Stucchi N, Carminati S, Ene-lordache B, Cravedi P, Remuzzi G. Effects of add-on fluvastatin therapy in patients with chronic proteinuric nephropathy on dual renin-angiotensin system blockade: the ESPLANADE trial. Clin J Am Soc Nephrol 2010; 5: 1928-38. 
27 Gupta K. The relationship between statin therapy and progression of renal damage among 10305 hypertensive patients randomised in the Ascot-lipid-lowering arm. 2011.

28 Lewis D, Emberson J, Collins AJ, Baigent C, collaboration ObotCTT. Effect of lowering LDL-cholesterol on kidney functino: meta-analysis of data from 120.000 participants in 21 randomized trials. J Am Soc Nephrol 2012; 23: (Suppl. 1): 685A.

29 Yusuf S, Sleight P, Pogue J, Bosch J, Davies R, Dagenais G. Effects of an angiotensin-converting-enzyme inhibitor, ramipril, on cardiovascular events in high-risk patients. The Heart Outcomes Prevention Evaluation Study Investigators. N Engl J Med 2000; 342: 145-53.

30 Dahlof B, Devereux RB, Kjeldsen SE, Julius S, Beevers G, de Faire U, Fyhrquist F, Ibsen $\mathrm{H}$, Kristiansson $\mathrm{K}$, Lederballe-Pedersen O, Lindholm LH, Nieminen MS, Omvik P, Oparil S, Wedel H. Cardiovascular morbidity and mortality in the Losartan Intervention For Endpoint reduction in hypertension study (LIFE): a randomised trial against atenolol. Lancet 2002; 359: 995-1003.

31 Kunz R, Friedrich C, Wolbers M, Mann JF. Meta-analysis: effect of monotherapy and combination therapy with inhibitors of the renin angiotensin system on proteinuria in renal disease. Ann Intern Med 2008; 148: 30-48.

32 Yusuf S, Teo KK, Pogue J, Dyal L, Copland I, Schumacher H, Dagenais G, Sleight $P$, Anderson C. Telmisartan, ramipril, or both in patients at high risk for vascular events. N Engl J Med 2008; 358: 1547-59.

33 Mann JF, Schmieder RE, McQueen M, Dyal L, Schumacher H, Pogue J, Wang X, Maggioni A, Budaj A, Chaithiraphan S, Dickstein K, Keltai M, Metsarinne K, Oto A, Parkhomenko A, Piegas LS, Svendsen TL, Teo KK, Yusuf S. Renal outcomes with telmisartan, ramipril, or both, in people at high vascular risk (the ONTARGET study): a multicentre, randomised, double-blind, controlled trial. Lancet 2008; 372: $547-53$.

34 Parving $\mathrm{HH}$, Brenner BM, McMurray JJ, de Zeeuw D, Haffner SM, Solomon SD, Chaturvedi N, Persson F, Desai AS, Nicolaides M, Richard A, Xiang Z, Brunel P, Pfeffer MA. Cardiorenal end points in a trial of aliskiren for type 2 diabetes. N Engl J Med 2012; 367: 2204-13.

35 Fried LF, Duckworth W, Zhang JH, O'Connor T, Brophy M, Emanuele N, Huang GD, McCullough PA, Palevsky PM, Seliger S, Warren SR, Peduzzi P. Design of combination angiotensin receptor blocker and angiotensin-converting enzyme inhibitor for treatment of diabetic nephropathy (VA NEPHRON-D). Clin J Am Soc Nephrol 2009; 4: 361-8.

36 Gansevoort RT, de Zeeuw D, Shahinfar S, Redfield A, de Jong PE. Effects of the angiotensin II antagonist losartan in hypertensive patients with renal disease. J Hypertens Suppl 1994; 12: S37-42.

37 Miao Y, Dobre D, Heerspink HJ, Brenner BM, Cooper ME, Parving $\mathrm{HH}$, Shahinfar S, Grobbee D, de Zeeuw D. Increased serum potassium affects renal outcomes: a post hoc analysis of the Reduction of Endpoints in NIDDM with the Angiotensin II Antagonist Losartan (RENAAL) trial. Diabetologia 2011; 54: 44-50.
38 Mohanram A, Zhang Z, Shahinfar S, Lyle PA, Toto RD. The effect of losartan on hemoglobin concentration and renal outcome in diabetic nephropathy of type 2 diabetes. Kidney Int 2008; 73: 630-6.

39 Miao Y, Ottenbros SA, Laverman GD, Brenner BM, Cooper $M E$, Parving $\mathrm{HH}$, Grobbee DE, Shahinfar S, de Zeeuw D, Lambers Heerspink $\mathrm{HJ}$. Effect of a reduction in uric acid on renal outcomes during losartan treatment: a post hoc analysis of the reduction of endpoints in non-insulin-dependent diabetes mellitus with the Angiotensin II Antagonist Losartan Trial. Hypertension 2011; 58: 2-7.

40 Slagman MC, Nguyen TQ, Waanders F, Vogt L, Hemmelder $\mathrm{MH}$, Laverman GD, Goldschmeding R, Navis G. Effects of antiproteinuric intervention on elevated connective tissue growth factor (CTGF/CCN-2) plasma and urine levels in nondiabetic nephropathy. Clin J Am Soc Nephrol 2011; 6: 1845-50.

41 Chrysostomou A, Becker G. Spironolactone in addition to ACE inhibition to reduce proteinuria in patients with chronic renal disease. N Engl J Med 2001; 345: 925-6.

42 Chrysostomou A, Pedagogos E, MacGregor L, Becker GJ. Double-blind, placebo-controlled study on the effect of the aldosterone receptor antagonist spironolactone in patients who have persistent proteinuria and are on long-term angiotensin-converting enzyme inhibitor therapy, with or without an angiotensin II receptor blocker. Clin J Am Soc Nephrol 2006; 1: 256-62.

43 Luther JM, Luo P, Wang Z, Cohen SE, Kim HS, Fogo AB, Brown NJ. Aldosterone deficiency and mineralocorticoid receptor antagonism prevent angiotensin II-induced cardiac, renal, and vascular injury. Kidney Int 2012; 82: 643-51.

44 Rossing K, Schjoedt KJ, Smidt UM, Boomsma F, Parving $\mathrm{HH}$. Beneficial effects of adding spironolactone to recommended antihypertensive treatment in diabetic nephropathy: a randomized, double-masked, cross-over study. Diabetes Care 2005; 28: 2106-12.

45 Roscioni SS, de Zeeuw D, Bakker SJ, Lambers Heerspink HJ. Management of hyperkalaemia consequent to mineralocorticoid-receptor antagonist therapy. Nat Rev Nephrol 2012; 8: 691-9.

46 Pitt B, Anker SD, Bushinsky DA, Kitzman DW, Zannad F, Huang IZ. Evaluation of the efficacy and safety of RLY5016, a polymeric potassium binder, in a double-blind, placebo-controlled study in patients with chronic heart failure (the PEARL-HF) trial. Eur Heart J 2011; 32: 820-8.

47 Fagart J, Hillisch A, Huyet J, Barfacker L, Fay M, Pleiss U, Pook E, Schafer S, Rafestin-Oblin ME, Kolkhof P. A new mode of mineralocorticoid receptor antagonism by a potent and selective nonsteroidal molecule. J Biol Chem 2010; 285: 29932-40.

48 Nariai T, Fujita K, Mori M, Katayama S, Hori S, Matsui K. SM-368229, a novel selective and potent non-steroidal mineralocorticoid receptor antagonist with strong urinary $\mathrm{Na}+$ excretion activity. J Pharmacol Sci 2011; 115: 346-53.

49 Hattori S. Sitagliptin reduces albuminuria in patients with type 2 diabetes. Endocr J 2011; 58:69-73. 
$\mathbf{5 0}$ von Eynatten M, Emser A, Cooper M, Perkovic V, Rosenstock J, Wanner C, Woerle HJ. Renal safety and outcomes with linagliptin: meta-analysis of individual data for 5466 patients with type 2 diabetes. J Am Soc Nephrol 2012; 23: (Suppl. 1): 218A.

51 Bailey CJ, Gross JL, Pieters A, Bastien A, List JF. Effect of dapagliflozin in patients with type 2 diabetes who have inadequate glycaemic control with metformin: a randomised, double-blind, placebo-controlled trial. Lancet 2010; 375: 2223-33.

52 Eschbach JW, Abdulhadi MH, Browne JK, Delano BG, Downing MR, Egrie JC, Evans RW, Friedman EA, Graber SE, Haley NR, Korbet S, Krantz SB, Lundin AP, Nissenson AR, Ogden DA, Paganini EP, Rader B, Rutsky EA, Stivelman J, Stone WJ, Teschan P, Van Stone JC, Van Wyck DB, Zuckerman K, Adamson JW. Recombinant human erythropoietin in anemic patients with end-stage renal disease. Results of a phase III multicenter clinical trial. Ann Intern Med 1989; 111:992-1000.

53 Association between recombinant human erythropoietin and quality of life and exercise capacity of patients receiving haemodialysis. Canadian Erythropoietin Study Group. BMJ 1990; 300: 573-8.

54 Pfeffer MA, Burdmann EA, Chen CY, Cooper ME, de Zeeuw $D$, Eckardt KU, Feyzi JM, Ivanovich P, Kewalramani R, Levey AS, Lewis EF, McGill JB, McMurray JJ, Parfrey P, Parving HH, Remuzzi G, Singh AK, Solomon SD, Toto R. A trial of darbepoetin alfa in type 2 diabetes and chronic kidney disease. N Engl J Med 2009; 361: 2019-32.

55 Singh AK, Szczech L, Tang KL, Barnhart H, Sapp S, Wolfson $\mathrm{M}$, Reddan D. Correction of anemia with epoetin alfa in chronic kidney disease. N Engl J Med 2006; 355: 2085-98.

56 Solomon SD, Uno H, Lewis EF, Eckardt KU, Lin J, Burdmann EA, de Zeeuw D, Ivanovich P, Levey AS, Parfrey P, Remuzzi G, Singh AK, Toto R, Huang F, Rossert J, McMurray JJ, Pfeffer MA. Erythropoietic response and outcomes in kidney disease and type 2 diabetes. $N$ Engl J Med 2010; 363: 1146-55.

$\mathbf{5 7}$ group KCw. KDIGO clinical practice guideline for the evaluation and management of chronic kidney disease. Kidney Int 2013; 23: (Suppl. 3): 1-150.

58 Teng M, Wolf M, Lowrie E, Ofsthun N, Lazarus JM, Thadhani R. Survival of patients undergoing hemodialysis with paricalcitol or calcitriol therapy. N Engl J Med 2003; 349: 446-56.

59 Agarwal R, Acharya M, Tian J, Hippensteel RL, Melnick JZ, Qiu P, Williams L, Batlle D. Antiproteinuric effect of oral paricalcitol in chronic kidney disease. Kidney Int 2005; 68: 2823-8.

60 Alborzi P, Patel NA, Peterson C, Bills JE, Bekele DM, Bunaye Z, Light RP, Agarwal R. Paricalcitol reduces albuminuria and inflammation in chronic kidney disease: a randomized double-blind pilot trial. Hypertension 2008; 52: 249-55.

61 Liu LJ, Lv JC, Shi SF, Chen YQ, Zhang H, Wang HY. Oral calcitriol for reduction of proteinuria in patients with $\lg A$ nephropathy: a randomized controlled trial. Am J Kidney Dis 2012; 59: 67-74.
62 de Zeeuw D, Agarwal R, Amdahl M, Audhya P, Coyne D, Garimella T, Parving HH, Pritchett Y, Remuzzi G, Ritz E, Andress $D$. Selective vitamin $D$ receptor activation with paricalcitol for reduction of albuminuria in patients with type 2 diabetes (VITAL study): a randomised controlled trial. Lancet 2010; 376: 1543-51.

63 Eddington H, Hoefield R, Sinha S, Chrysochou C, Lane B, Foley RN, Hegarty J, New J, O'Donoghue DJ, Middleton RJ, Kalra PA. Serum phosphate and mortality in patients with chronic kidney disease. Clin J Am Soc Nephrol 2010; 5: 2251-7.

64 Hovind $P$, Rossing $P$, Tarnow L, Johnson RJ, Parving $\mathrm{HH}$. Serum uric acid as a predictor for development of diabetic nephropathy in type 1 diabetes: an inception cohort study. Diabetes 2009; 58: 1668-71.

65 Bellomo G, Venanzi S, Verdura C, Saronio P, Esposito A, Timio M. Association of uric acid with change in kidney function in healthy normotensive individuals. Am J Kidney Dis 2010; 56: 264-72.

66 Kang DH, Park SK, Lee IK, Johnson RJ. Uric acid-induced C-reactive protein expression: implication on cell proliferation and nitric oxide production of human vascular cells. J Am Soc Nephrol 2005; 16: 3553-62.

67 Sautin YY, Nakagawa T, Zharikov S, Johnson RJ. Adverse effects of the classic antioxidant uric acid in adipocytes: NADPH oxidase-mediated oxidative/nitrosative stress. Am J Physiol Cell Physiol 2007; 293: C584-96.

68 Perlstein TS, Gumieniak O, Hopkins PN, Murphey LJ, Brown NJ, Williams GH, Hollenberg NK, Fisher ND. Uric acid and the state of the intrarenal renin-angiotensin system in humans. Kidney Int 2004; 66: 1465-70.

69 Goicoechea M, de Vinuesa SG, Verdalles U, Ruiz-Caro C, Ampuero J, Rincon A, Arroyo D, Luno J. Effect of allopurinol in chronic kidney disease progression and cardiovascular risk. Clin J Am Soc Nephrol 2010; 5: 1388-93.

70 Whelton A, Macdonald PA, Zhao L, Hunt B, Gunawardhana L. Renal function in gout: long-term treatment effects of febuxostat. J Clin Rheumatol 2011; 17: 7-13.

71 Wang $H$, Wei Y, Kong X, Xu D. Effects of urate-lowering therapy in hyperuricemia on slowing the progression of renal function: a meta-analysis. J Ren Nutr 2012; 12: s1051-2276.

72 Dhaun N, Goddard J, Webb DJ. The endothelin system and its antagonism in chronic kidney disease. J Am Soc Nephrol 2006; 17: 943-55.

73 Kohan DE, Pollock DM. Endothelin antagonists for diabetic and non-diabetic chronic kidney disease. Br J Clin Pharmacol 2013; 76: 573-9.

74 Zoja C, Morigi M, Figliuzzi M, Bruzzi I, Oldroyd S, Benigni A, Ronco P, Remuzzi G. Proximal tubular cell synthesis and secretion of endothelin-1 on challenge with albumin and other proteins. Am J Kidney Dis 1995; 26: 934-41.

75 Sasser JM, Sullivan JC, Hobbs JL, Yamamoto T, Pollock DM, Carmines PK, Pollock JS. Endothelin A receptor blockade reduces diabetic renal injury via an anti-inflammatory mechanism. J Am Soc Nephrol 2007; 18: 143-54. 
76 Achmad TH, Rao GS. Chemotaxis of human blood monocytes toward endothelin-1 and the influence of calcium channel blockers. Biochem Biophys Res Commun 1992; 189: 994-1000.

77 Mann JF, Green D, Jamerson K, Ruilope LM, Kuranoff SJ, Littke T, Viberti G. Avosentan for overt diabetic nephropathy. J Am Soc Nephrol 2011; 21:527-35.

78 Hoekman J, Lambers Heerspink HJ, Viberti G, Green D, Mann JF, De Zeeuw D. Body weight increase and congesitve heart failure during treatment with avosentan: a post-hoc analysis of the ASCEND trial. J Am Soc Nephrol 2012; 23: (Suppl. 1): 753A.

79 Dhaun N, Melville V, Blackwell S, Talwar DK, Johnston NR, Goddard J, Webb DJ. Endothelin-A receptor antagonism modifies cardiovascular risk factors in CKD. J Am Soc Nephrol 2013; 24:31-6.

80 Kohan DE, Pritchett Y, Molitch M, Wen S, Garimella T, Audhya P, Andress DL. Addition of atrasentan to renin-angiotensin system blockade reduces albuminuria in diabetic nephropathy. J Am Soc Nephrol 2011; 22: 763-72.

81 Henique C, Tharaux PL. Targeting signaling pathways in glomerular diseases. Curr Opin Nephrol Hypertens 2012; 21:417-27.

82 Itoh K, Tong KI, Yamamoto M. Molecular mechanism activating Nrf2-Keap1 pathway in regulation of adaptive response to electrophiles. Free Radic Biol Med 2004; 36: 1208-13.

83 Ruiz S, Pergola PE, Zager RA, Vaziri ND. Targeting the transcription factor Nrf2 to ameliorate oxidative stress and inflammation in chronic kidney disease. Kidney Int 2013; 83: 1029-41.

84 Pergola PE, Krauth M, Huff JW, Ferguson DA, Ruiz S, Meyer CJ, Warnock DG. Effect of bardoxolone methyl on kidney function in patients with T2D and Stage 3b-4 CKD. Am J Nephrol 2011; 33:469-76.

85 Pergola PE, Raskin P, Toto RD, Meyer CJ, Huff JW, Grossman EB, Krauth M, Ruiz S, Audhya P, Christ-Schmidt H, Wittes J, Warnock DG. Bardoxolone methyl and kidney function in CKD with type 2 diabetes. N Engl J Med 2011; 365: 327-36.

86 De Zeeuw D, Akizawa T, Agarwal R, Audhya P, Bakris G, Chin M, Krauth M, Lambers Heerspink HJ, Meyer CJ, McMurray JJ, Parving HH, Remuzzi G, Toto R, Vaziri ND, Wanner C, Wittes J, Chertow GM. Bardoxolone methyl EvAluation in patients with Chronic kidney disease and type 2 diabetes: the Occurrence of renal eveNts (BEACON): rationale and trial design. Am J Nephrol 2013; 37: 212-22.

87 McCormick BB, Sydor A, Akbari A, Fergusson D, Doucette S, Knoll G. The effect of pentoxifylline on proteinuria in diabetic kidney disease: a meta-analysis. Am J Kidney Dis 2008; 52: 454-63.

88 Navarro-Gonzalez JF, Muros M, Mora-Fernandez C, Herrera $\mathrm{H}$, Meneses B, Garcia J. Pentoxifylline for renoprotection in diabetic nephropathy: the PREDIAN study. Rationale and basal results. J Diabetes Complications 2011; 25: 314-9.

89 Aslanian A, Hogan K, West K, Bridson GW, Wu L. CTP499, a novel drug for the treatment of chronic kidney disease, ameliorates fibrosis and renal inflammation in vivo. J Am Soc Nephrol 2012; 23: (Suppl. 1): 326A.

90 Amann B, Tinzmann R, Angelkort B. ACE inhibitors improve diabetic nephropathy through suppression of renal MCP-1. Diabetes Care 2003; 26: 2421-5.

91 Ruggenenti P. Effects of MCP-1 inhibition by bindarit therapy in type 2 diabetes subjects with micro- or macro-albuminuria. J Am Soc Nephrol 2010; 21: (Suppl. 1): $44 \mathrm{~A}$.

92 Sullivan T, Miao Z, Berahovich RD, Powers JP, Baumgart T, Ertl L, Miao S, Schall TJ, Jaen JC. The CCR2 chemokine receptor antagonist CCX-140 improves renal function in diabetic mice expressing human CCR2. J Am Soc Nephrol 2012; 23: (Suppl. 1): 746A.

93 Yamamoto S, Zuo Y, Ma J, Yancey PG, Hunley TE, Motojima $M$, Fogo AB, Linton MF, Fazio S, Ichikawa I, Kon V. Oral activated charcoal adsorbent (AST-120) ameliorates extent and instability of atherosclerosis accelerated by kidney disease in apolipoprotein E-deficient mice. Nephrol Dial Transplant 2011;26: 2491-7.

94 Schulman G, Berl T, Beck G, Remuzzi G, Ritz E. Results from two randomized placebo controlled double blind clinical trials of AST-120 in adults with CKD. J Am Soc Nephrol 2012; 23: (Suppl. 1): 7B.

95 Lewis EJ, Greene T, Spitalewiz S, Blumenthal S, Berl T, Hunsicker LG, Pohl MA, Rohde RD, Raz I, Yerushalmy Y, Yagil Y, Herskovits T, Atkins RC, Reutens AT, Packham DK, Lewis JB. Pyridorin in type 2 diabetic nephropathy. J Am Soc Nephrol 2011; 23: 131-6.

96 Alkhalaf A, Klooster A, van Oeveren W, Achenbach U, Kleefstra N, Slingerland RJ, Mijnhout GS, Bilo HJ, Gans RO, Navis GJ, Bakker SJ. A double-blind, randomized, placebo-controlled clinical trial on benfotiamine treatment in patients with diabetic nephropathy. Diabetes Care 2010; 33: 1598-601.

97 House AA, Eliasziw M, Cattran DC, Churchill DN, Oliver MJ, Fine A, Dresser GK, Spence JD. Effect of B-vitamin therapy on progression of diabetic nephropathy: a randomized controlled trial. Jama 2010; 303: 1603-9.

98 Gaede P, Vedel P, Larsen N, Jensen GV, Parving HH, Pedersen O. Multifactorial intervention and cardiovascular disease in patients with type 2 diabetes. $N$ Engl J Med 2003; 348: 383-93.

99 Ruggenenti P, Perticucci E, Cravedi P, Gambara V, Costantini M, Sharma SK, Perna A, Remuzzi G. Role of remission clinics in the longitudinal treatment of CKD. J Am Soc Nephrol 2008; 19: 1213-24.

100 Parving $\mathrm{HH}$, de Zeeuw D, Cooper ME, Remuzzi G, Liu N, Lunceford J, Shahinfar S, Wong PH, Lyle PA, Rossing P, Brenner BM. ACE gene polymorphism and losartan treatment in type 2 diabetic patients with nephropathy. J Am Soc Nephrol 2008; 19: 771-9.

101 Heerspink HJ, Holtkamp FA, Parving HH, Navis GJ, Lewis JB, Ritz E, de Graeff PA, de Zeeuw D. Moderation of dietary sodium potentiates the renal and cardiovascular protective effects of angiotensin receptor blockers. Kidney Int 2012; 82: 330-7. 
102 Mallamaci F, Ruggenenti P, Perna A, Leonardis D, Tripepi R, Tripepi G, Remuzzi G, Zoccali C. ACE inhibition is renoprotective among obese patients with proteinuria. J Am Soc Nephrol 2011; 22: 1122-8.

103 Lufft V, Kliem V, Hamkens A, Bleck JS, Eisenberger U, Petersen R, Ehlerding G, Maschek H, Pichlmayr R, Brunkhorst R. Antiproteinuric efficacy of fosinopril after renal transplantation is determined by the extent of vascular and tubulointerstitial damage. Clin Transplant 1998; 12: 409-15.

104 Roscioni S, Miao Y, De Zeeuw D, Lambers Heerspink HJ. Response to: Miao Y, Dobre D, Lambers Heerspink HJ et al. (2011) Increased serum potassium affects renal outcomes: a post hoc analysis of the Reduction of Endpoints in
NIDDM with the Angiotensin II Antagonist Losartan (RENAAL) trial. Diabetologia 2011; 54: 2965-7.

105 Chapman AB, Torres VE, Perrone RD, Steinman TI, Bae KT, Miller JP, Miskulin DC, Rahbari Oskoui F, Masoumi A, Hogan MC, Winklhofer FT, Braun W, Thompson PA, Meyers CM, Kelleher C, Schrier RW. The HALT polycystic kidney disease trials: design and implementation. Clin J Am Soc Nephrol 2011; 5: 102-9.

106 Packham D, Wolfe R, Reutens AT, Berl T, Lambers Heerspink HJ, Rohde R, Ivory S, Lewis J, Raz I, Zd D, Lewis EJ, Atkins RC. The effect of sulodexide in overt type 2 diabetic nephropathy trial: observations following its early termination. J Am Soc Nephrol 2012; 23: 123-30. 